carpella 2, distineta, disco longiora; stylus brevis; stigma ovoideum exannulatum, apiculo conico breviter 2-fido. Folliculi divaricati continui, teretes, $10 \mathrm{~cm}$. longi, $4 \mathrm{~mm}$. in sectione requantes. Semina in folliculo pauca, oblonga, $11 \mathrm{~mm}$. longa, $3 \mathrm{~mm}$. lata, compressa, a pice parum contracta ; coma $4 \mathrm{~cm}$. longa caduca et annulo pilorum brevium persistente coronata; albumen copiosum ; cotyledones oblonga, foliacere ; radicula longa, cotyledones in longituline requans.

Hab. Shinkō, Shintiku, leg. 'T. Kawakami, anno 1906 (Mart. Fl.).

It was suggested to me by Mr. T. Kawakam that this species may belong to Urceola. Studying this point carefully, I think that the plant should be referred to Ecdysanthera on account of its glands within the sepals, and its lobes of the corolla being imbricate. This new species resembles E. densiflora Miq. (Fl. Ind. Bat. II. p. 4.52); but differs from it by the long petioled leaves and flowers.

\title{
Contributions to the Flora of Mt. Morrison.
}

by

\author{
B. HAYATA. \\ Assistant in the Botanical Institute, Science College, \\ Imperial University of Tokiy $\overline{\text { o. }}$
}

Bœhnninghausenia albiflora ReICH. "Conspect. Reg. Veg. p. 197"; Hook. f. Fl. Brit. Ind. I. p. 486 ; Hance, in Journ. Bot. (1874) p. 259 ; Franchet, Pl. David. p. 66 ; Franch. et Sav. Enum. Pl. Jap. I. p. 71 ; Miq. Prol. Fl. Jap. p. 209 ; Engl. in Eng. et Prant. Nat. Pfl. fam. III. -4, p. 130 ; Forbes et Hemse. Ind. Fl. Sin. I. p. 102 ; Diers, Fl. Centr. Chin. in Engt. Bot. Jahrb. XXIX. p. 423.

Hab. 'Tōhosha, ad 2930 ped., (No. 706); Tatsuhō, ad 3139 ped., (No. 716); Sanchōkei, ad 4000 ped., (No. 725), leg. S. Nagasawa, anno 1905. Nov.

Distrib. Monotype. Khasia, in the temperate regions of Himalaya; also in mountainous district of China and Japan, but not in any neighbouring country farther south than Formosa.

Paris lancifolia Hayata n. sp. Rhizoma... Canlis simplex, circ. $50 \mathrm{~cm}$, longus. Folia 7-8, arl apicem caulis verticillata, sessilia, lanceolato- 
linearia, acuminata, circ. $12 \mathrm{~cm}$. longa, $1 \mathrm{~cm}$. lata, 1-nervia, reticulato-venulosa. Flos unicus inter folia pedicellatus, pedicello $7 \mathrm{~cm}$. longo erecto. Perianthium persistens; segmenta distincta, 5-seriata, exteriora patentissima, herbacea, lanceolata, acuminata, $6-5 \mathrm{~cm}$. longa, $7-8 \mathrm{~mm}$. lata, basi inter sinuata, interiora filiformia $2 \frac{1}{2}-3 \mathrm{~cm}$. longa. Bacca ignota.

Hab. Morrison: Ganzan ad. 9141 ped., leg. S. Nagasawa, (No. 693)

This new plant very much resembles Japanese P. quadrifolia L. var. obovata REG. et TIL; but differs by the lanceolato-linear leaves and filiformed petals. This is the only one species of Paris found in Formosa.

This genus is spread over Europe westwards from Altai, Siberia, Himalaya, China and Japan. The species belonging to the genus are 8 in central China and 3 in Japan.

Heptapleurum racemosum Bedd. Fl. Sylv. t. 214 ; C. B. Clarke, in Hook. f. Fl. Brit. Ind. II. p. 729.

Hedera racemosa Wight Ic. Pl. Ind. Or. t. 1015.

Agalma racemosum Seem. "Rev. Heder. p. 24."

Folia digitata, petiolis $20 \mathrm{~cm}$. longis, foliolis 7 , lanceolatis acuminatis majoribus $16 \mathrm{~cm}$. longis, petiolulis $1-1.5 \mathrm{~cm}$. longis. Pedunculi pauci-ramosi, 25-30 cm. longi, pedicellis fasciculato-racemosis, umbellam non formantibus.

Hab. Morrison: Ganzan ad 9141 ped., leg. S. Nagasawa (No. 565), Nov. 1905 ; T. Kawakami et G. Nakahalia.

This plant is found in the mountainous district of southern India such as Neilghirries at the altitude of $3000-5000 \mathrm{ft}$, and also in Ceylon at the altitude of 3000-5000 ft. (after Beddome); but not found in Himalaya. It is a rather anomalous case that such a southern species is found in the alpine region of Formosa. No species of this genus has yet been known from central China.

Gynostemma pedatum Blune; Walp. Rep. I. p. 98 ; MıQ. Fl. Ind. Bat. I.-1, p. 683 ; ClaAkKe, in Hook. f. Fl. Brit. Ind. II. p. 633, Cogn, in DC. Monogr. Phanerog. III. p. 913 ; Flianche'l, Pl. David. I. p. 136 ; Forbes et Hemsl. Ind. Fl. Sin. I. p. 320 ; Itō et Matsum. Tent. Fl. Lutch. p. 519; Diels, Fl. Centr. Chin. in Engl. Bot. Jahrb. XXIX. p. 604.

Gynostemma cissoides Benth. et Hook. Gen. Pl. I. p. 839 ; Franch. et Sav. Enum. Pl. Jap. I. p. 176. 
Enkylia trigyna Griffish.; MıQ. Prol. Fl. Jap. pp. 15 et 14.. Pestalozaia pedata Zolr. et Mor., Walp. Ann. I. p. 316.

Zanonia cissoides Wall.; Walp. Rep. II. p. 194.

Zanonia pedata MıQ. Fl. Ind. Bat. I.-1, p. 683.

Hab. Morrison, leg. S. Nagasawa.

Distrib. Himalaya, Java, Malay, centro-east China, Japan and Loo-choo.

Mitella japonica MiQ. Ann. Mus. Bot. Iungd. Bat. III. pp. 96 et 201, et Prol. Fl. Jap. pp. 260 et 365 ; Flanch. et Sav. Enum. Pl. Jap. I. p. 147 excl. syn. (non Maxim.); Makino, in Icon. Fl. Jap. Imp. Uni. 'Tokyō, I.-2, p. 7, Pl. IV. et V.

Hab. Morrison: Shūkorankei, ad. 11157 ped., leg. S. Nagasawa (No. $613)$; et T. Kawakami et G. Nakahara, Nov. 1905.

Distrib. in Japan; common among the valleys of the lowland hills. This genus Mitella is limited to North America, Japan and Formosa.

My Morrison specimen is a form of rather more divaricate and fimbriate petals and less tuberculated seeds.

\section{Salix sp.}

Hab. Morrison, ad 13094 ped., leg. S. Nagasawa, (No. 596), anno 1905, Nov.

It somewhat resembles Japanese S. Sieboldiana Br. The specimen being sterile, the specific name is indeterminable.

Cardiandra formosa na Hаунта n. sp. Suffrutex, pilosiusculus, ramis teretibus. Folia alterna, lanceolata, utrinque attenuata, grosse serrata, serris ascendentibus acutis, $10-15 \mathrm{~cm}$. longa, $4-6 \mathrm{~cm}$. lata, subtus pallidiuscula, petiolata, petiolis $3-4 \mathrm{~cm}$. longis. Stipulse $O$. Flores parvi, laxe paniculatocorymbosi ; corymbi longe pedunculati, 20-30 cm. longi ; ramis 5-8, 6-7 cm. longis basi bracteatis, bracteis linearibus; fl. exteriores in corymbo steriles, longe pedicellati, pedicellis 1-2 cm. longis; calycis limbo 2-foliato, altero majore, altero minore, petaloideo obcordato, $1-2 \frac{1}{2} \mathrm{~cm}$. longo, venoso; fl. interiores in corymbo fertiles ; calycis tubus ovario adnatus, hemisphericus, lobis 5 rarius 4 , triangularibus ovatis valvatis; petala 5 , rarius 4 , imbricata, ovata, $2 \mathrm{~mm}$. lata. Stamina perplurima, epigyna, multiseriata, filamentis filiformi- 
bus; antheræ obcordato-truncatæ, basifixæ, loculis linearibus a basi divergentibus, connectivo sursum dilatato. Ovarium inferum, complete 3-loculare; plasentis axillaribus; styli 3, rarius 2, liberi, breviusculi, subconici, stigmatis subcapitatis. Capsula hemispherica, calycis limbis persistentibus. Semina ut C. alternifolia.

Hab. 'Tatsuhö, ad 3138 ped., leg. S. Nagasawa (No. 714), anno 1905.

This new species differs from the Japanese species by its 2-foliate limb of the calyx of the sterile flowers, and long lanceolate leaves.

Rubus pectinellus Maxim. in Mél. Biol. VIII. p. 374 ; Franch. et Sav. Enum. Fl. Jap. I. p. 122.

Hab. Morrison: Suizan, ad 7702 ped., leg. S. Nagasawa, (No. 6.51), anno 1905, Nov; et T. Kawakami et G. Nakahara.

Widely spread in the mountainous districts of Japan (from Honshū up to Kiushiu); but not known from China or Himalaya. It is very remarkable matter that we have found this plant in the alpine regions of Formosa.

My Morrison specimen is a less villose form.

Aucuba japonica Thuns. Fl. Jap. pp. 4 et 64 , tt. 12 et 13 ; Will.d. Sp. Pl. IV. p. 328 ; Bot. Mag. tt. 1197 et 5512 ; DC. Prodr. IV. 1. 274; Miq. Prol. Fl. Jap. p. 92 ; Franch. et Sav. Enum. Pl. Jap. p. 197 ; Henry, List Pl. Formos. p. 48 ; Forbes. et Hemsl. Ind. Fl. Sin. I. p. 346 ; Trō et Matsur. Tent. Fl. Lutch. p. 541 ; Diels, Fl. Cent. Chin. in Engi. Bot. Jahrb. XXIX. p. 507 ; Palibin, Conspect. Fl. Korere, I. p. 102.

Aucuba himalaica Hook. f. Fl. Brit. Ind. II. p. 747.

Aucuba chinensis Bentr. F]. Hongk. p. 138.

Hab. Morrison.

The Formosan specimen is somewhat different from the Japanese species. The flowers are rather larger, leaves narrower, oblanceolate, with more diverged second veinlets. I suspect if this may not be a variety of the Japanese species.

Distrib. from middle Himalaya through central China up to Japan and Corea.

Skimmia japonica Thunb. Fl. Jap. pp. 4 et 62 ; Franch. et Sav. 
[Vol. $\mathbf{x x}$,

Ĺnum. Pl. Jap. II. p. 311 ; 1)C. Prodr. II. p. 18 ; Itō et Matsum. Tent. Fl. Lutch. p. 357 ; Diess, Fl. Centr. Chin. in Engl. Bot. Jahrb. XXIX. 1. 424.

Hab. Morrison, leg. S. Nagasawa, anno 1905, Nov.

This monotypic species (S. Fortunei $\mathrm{M}_{\mathrm{AST}}$ is only a form of $\mathrm{S}$. japonica Thunb) ranges through Afghanistan to Japan; but not yet found in any region farther south than Formosa. Mt Morrison is, therefore, a southern limitation of the genus Skimmia.

Ribes formosanum HAYATA sp. nov. Frutices, ramulis angularibus spinis infra-axillaribus ternis validis patentibus (medio validiore.) Folia simplicia, vernatione plicata rotundata basi truncata vel cordata, $2 \frac{1}{2} \mathrm{~cm}$. longa 5-6-lobata, lobis obtusis grosse pauce serratis, peliolata, petiolis parce glanduloso-setosis lamium æquantibus. Flores subsolitalii pedicellis $1 \mathrm{~cm}$. longis, basi bracteatis et medio articulatis $2-4$ bracteolatis. Calycis tubus ovoideus, ovario adnatus; limbus tubulosus, subcylindricus $8 \mathrm{~mm}$. longus, 5-fidus, lobis erectis lanceolatis $8 \mathrm{~mm}$. longis, corollam 2 -plo superantibus. Petala 5 , calycis fauce inserta parva squamiformia, inclusa $4 \mathrm{~mm}$. longa. Stamina $5,4 \mathrm{~mm}$. longa, filamentis brevibus; anthere longa. Ovarium inferum, 1-loculare; styli 2, distincti basi leviter connati, stigmatibus simplicibus ; ovula numerosa, placentis 2 , parietalibus. Bacca ovoidea, rosea, pulposa, $1 \frac{1}{2} \mathrm{~cm}$. longa, sepalis persistentibus. Semina subangulata, testa extus gelatinosa intus crustacea, $4 \mathrm{~mm}$. longa, leviter compressa.

Hal. Morrison: Tōbokei, ad 5907 ped., leg. S. Nagasawa, (No. 592), anno 1905, Nov; et 'T. Kawakami et G. Narahara.

\section{ERRATA IN THE PRECEDING NUMBER.}

Page 16, line 3, for "niitakayamense read: niitakayamensi.

— 19, — 13, for "Parnasia" read: Parnassia.

— 22, _ 7 , for "nïtakayamence" read : niitakayamense. 